\title{
Morphology Comparison of Swiftlet Species from Natural and Man-Made Habitats in Malaysia
}

(Perbandingan Morfologi Spesies Burung Walit daripada Habitat Semula Jadi dan Buatan di Malaysia)

\author{
LOOI QI HAO, AINI IDERIS, MD ZUKI BIN ABU BAKAR @ ZAKARIA \&
} ABDUL RAHMAN BIN OMAR*

\begin{abstract}
In Malaysia, nests of Aerodramus fuciphagus (white-nest swiftlet) and Aerodramus maximus (black-nest swiftlet) are harvested for commercial purposes, as one of the most valuable animal products. The taxonomy of a species is crucial, as delineating species boundaries is fundamental to discover life's diversity. However, swiftlet taxonomy has been controversial, due to numerous undefined parameters. Although there are these limitations, morphological taxonomy cannot be the unique approach for species identification and it is a valuable component in taxonomy studies. We have undertaken a morphological approach to analyse community relationships among species of swiftlets. In this study, we selected three different swiftlet species to generate two sets of comparisons: Within species and among different habitats. This study found that $\mathrm{A}$. fuciphagus from man-made habitats is generally larger in size compared to the natural habitat and A. maximus is larger compared with A. fuciphagus. We postulate the difference in body size is due to dietary behaviour and genetic variations of the swiftlets.
\end{abstract}

Keywords: Black-nest swiftlet; habitats; morphology; species; white-nest swiftlet

ABSTRAK

Di Malaysia, sarang Aerodramus fuciphagus (burung walit sarang-putih) dan Aerodramus maximus (burung walit saranghitam) dituai untuk tujuan komersial dan ia merupakan salah satu produk haiwan yang paling berharga. Taksonomi spesies amat penting demi mengkaji kepelbagaian hidupan. Walau bagaimanapun taksonomi burung walit telah menimbulkan beberapa kontroversi kerana terdapat parameter yang kurang jelas. Walaupun taksonomi berdasarkan morfologi bukan pendekatan yang unik untuk pengenalpastian spesies kerana beberapa kekangan, ia merupakan komponen penting dalam kajian taksonomi. Kami telah menggunakan pendekatan morfologi untuk mengkaji kaitan komuniti dalam kalangan spesies burung walit. Kami telah menggunakan tiga spesies burung walit untuk menjana dua jenis perbandingan: Antara spesies dan antara pelbagai habitat. Kajian ini mendapati bahawa A. fuciphagus dari habitat buatan manusia secara umumnya mempunyai saiz lebih besar berbanding dengan A. fuciphagus daripada habitat semula jadi dan A. maximus adalah lebih besar berbanding dengan A. fuciphagus. Kami mengandaikan bahawa perbezaan saiz badan adalah disebabkan oleh pemakanan dan variasi genetik burung walit.

Kata kunci: Burung walit sarang hitam; burung walit sarang putih; habitat; morfologi; spesies

\section{INTRODUCTION}

Taxonomy of a species is important, as delineating species boundaries is fundamental to discover life's diversity (Dayrat 2005). Therefore, identification should be efficient and systematic. Yet, classification of swiftlet species is still poorly resolved and open to debate (Chantler \& Driessens 2000; Mayr 1942). The debate regarding ways to classify swiftlet species is primarily between proponents for morphological or molecular evidence. Although morphology taxonomy cannot be the unique approach for species identification due to some constraints, it is a valuable component in taxonomy studies.

Swiftlets are a group of small swifts (Aves, Apodidae) extending over a wide range of habitats from the islands of the western Indian Ocean, southern continental Asia, the
Philippines, north Australia and the west and southwest Pacific (Medway 1966). In Malaysia, the swiftlet colonises both natural limestone caves, located mainly in Sabah and Sarawak and man-made structures that resemble those caves, with controlled microenvironments (air temperature, air velocity, structure design and relative humidity) (Lim et al. 2002). Sibley (1990) concluded that there is a total of 31 species in the genus Collocalia, while in Malaysia it consists of six species, of which only nests from Aerodramus fuciphagus and Aerodramus maximus are harvested commercially (Viruhpintu et al. 2002).

Swiftlet is among the complicated bird groups in bird taxonomy, due to the lack of distinguishing morphological characteristics (Chantler \& Driessens 2000). In the past, the phylogenetic arrangement for the swiftlet was controversial 
and has been shuffled several times. Some studies have tried to define swiftlet taxonomy based on archaeological sequences, morphological characteristics, ability to echolocate, and molecular markers (Brooke 1970; Chantler \& Driessens 2000; Lee et al. 1996; Mayr 1942; Price et al. 2004; Salomonsen 1983; Sibley 1990; Thomassen et al. 2005 , 2003). However to date, no study can establish the swiftlet taxonomy based on a single determinant.

In Malaysia, Hydrochous gigas and Colocalia esculenta are the only two species that can be readily identified based on size variation and colour pattern (Sims 1961). Previous researchers have deduced the phylogenetic relationships based on morphological characteristics, including the degree of feathering of the tarsus, bill shape, crown and throat feather structure, the presence or absence of white downy tips on the feathers, and the ability to echolocate (Brooke 1970; Mayr 1941; Oberholser 1906). Mayr's (1942) review inferred that a precise and effective classification can be derived from careful evaluation of all such characteristics, yet there was often a lack of standardised measurement of these characteristics, so accurate measurement was not possible. However, Medway (1966) suggested that pigmentation of the mantle and rump feathers; and feathering of the tarsus, act as the two most important taxonomic traits for the swiftlets. The goal of this study was to elucidate previously unstudied or little-known aspects of body size comparison, between swiftlet species from different habitats in Malaysia.

\section{MATERIALS AND METHODS}

\section{SAMPLE COLLECTION}

This study involved a total of 85 A. fuciphagus (47 from man-made bird houses and 38 from the natural cave) and
19 A. maximums specimens. The swiftlets were captured using mist net in Perak (N04'20.824' E100 $52.826^{\circ}$ '), Terengganu (N05 $01.966^{\prime}$ E $\left.103^{\circ} 01.260^{\prime}\right)$, Selangor (N03 ${ }^{\circ} 40.5^{\prime}$ E101 ${ }^{\circ} 42.8 .7^{\prime}$ ) and Gomantong Cave, Sandakan, Sabah (N5³1 .46.5 E118 $4^{\prime}$.29.6). The foraging habitats of swiftlet colonies were observed over the sampling period. The species of swiftlet was confirmed by sequencing of the cytochrome $b$ gene, based on DNA sequences from GenBank $^{\circledR}$ accession numbers EU072065.1 and U50000.1 (unpublished results).

\section{SAMPLE MEASUREMENT}

Morphological analysis, including the weight of the bird, body length, wing length (flattened), extended wing span, outer tail length, tarsus length and bill length was performed (Figure 1). The measurements of the swiftlets were taken with callipers to $0.05 \mathrm{~mm}$ and with a metallic ruler to $0.5 \mathrm{~mm}$. The mass of the birds was obtained with a Sartorius ${ }^{\circledR}$ BL $1500 \mathrm{~S}$ electronic balance to $0.1 \mathrm{~g}$.

\section{STATISTICAL ANALYSIS}

Statistical software, IBM ${ }^{\circledR}$ SSPS for Microsoft Windows ${ }^{\circledR}$ version 21.0, was used to analyse the data. All results are reported as mean $\pm \mathrm{SE}$.

\section{RESULTS}

\section{HABITAT COMPARISON}

Sampling of swiftlets from man-made bird houses was carried out from November 2012 to August 2013 in the states of Perak, Terengganu and Selangor. Meanwhile, sampling of swiftlets from the limestone Gomantong Caves in Sabah was carried out from April to December

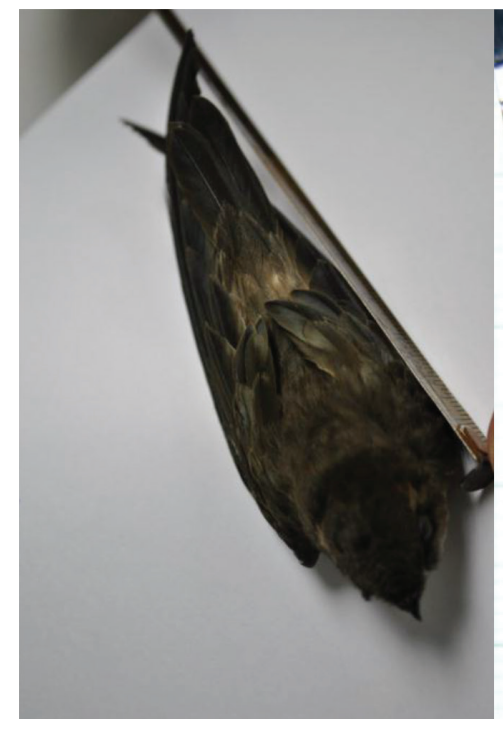

(a)

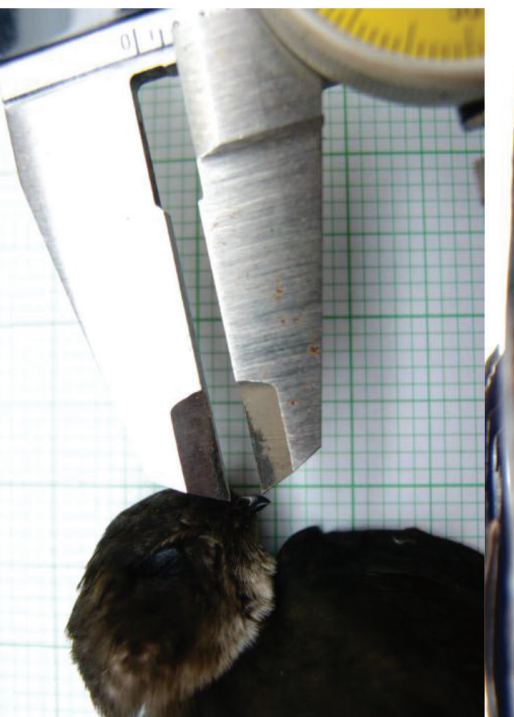

(b)

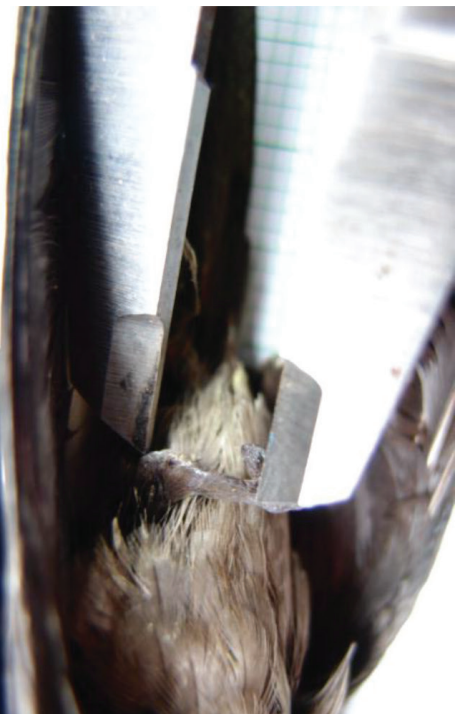

(c)

FIGURE 1. Measurement of sample size. (a): wing cord, (b): bill length and (c): tarsus length 
2013. The morphological traits of the white-nest swiftlet (weight, wing chord, wingspan, bill length, tarsus length, body length and tail length) from the natural cave and manmade bird houses were compared and statistically analysed. One-way MANOVA showed a significant multivariate main effect for habitats: Wilks' $\lambda=0.389, F=16.135$, $p<0.001$ and partial eta squared $=0.611$. The power used to detect the effect was 1.000 . Thus, the body size of $A$. fuciphagus from various habitats differs significantly. Given the significance of the overall test, the univariate main effects for habitats were examined for weight: $F=$ $24.639, p<0.0014$, partial eta square $=0.240$, and power $=0.933$; wing cord: $F=13.764, p<0.0014$, partial eta square $=0.150$, and power $=0.614$; wing span: $F=18.797$, $p<0.0014$, partial eta square $=0.194$, and power $=0.814$; and tail length: $F=0.421, p<0.0014$, partial eta square $=0.310$, and power $=0.992$. However, no significant differences were detected on tarsus length, bill length and body length of white-nest swiftlets from the different habitats. Based on the comparison of estimated marginal mean, the size of A. fuciphagus from the natural cave is smaller compared to A. fuciphagus colonised at man-made bird houses (Table 1, Figure 2).

Analysis and comparison of the morphological differences of white-nest and black-nest swiftlets from the natural cave habitat were carried out as described above. One-way MANOVA showed a significant multivariate main effect for habitats: Wilks' $\lambda=0.242, F=21.041, p<0.001$ and partial eta squared 0.758 . The power to detect the effect was 1.000 . Thus the body size of $A$. fuciphagus and A. maximus differ significantly. Given the significance of the overall test, the univariate interspecies main effects were examined for weight: $F=92.225, p<0.0014$, partial eta square $=0.635$ and power $=1.000$; wing cord: $F=$ $17.923, p<0.0014$, partial eta square $=0.253$ and power $=0.766$; wing span: $F=88.197, p<0.0014$, partial eta square $=0.624$ and power $=1.000$; tarsus: $F=32.508$, $p<0.0014$, partial eta square $=0.380$, and power $=0.983$; and bill length: $F=14.421, p<0.0014$, partial eta square $=0.214$, and power $=0.623$. However, the tail length and body length measurements were not significantly different for each species. Based on comparison of the estimated marginal means, the size of A. maximus was larger than A. fuciphagus (Table 2, Figure 3).

\section{DISCUSSION}

In this study, we focused on intra-species morphological comparison within white-nest swiftlets from different habitats and inter-species morphological comparison between white-nest swiftlets and black-nest swiftlets. We postulated the morphological variations of swiftlets are due to two main factors: Dietary behaviour and genetic variations. Dietary behaviours are presumed to be dominant

TABLE 1. Comparison of growth parameters between A. fuciphagus from man-made and natural habitats

\begin{tabular}{|c|c|c|c|c|c|c|}
\hline \multirow[t]{3}{*}{ Dependent Variable } & \multicolumn{4}{|c|}{ Habitats } & \multicolumn{2}{|c|}{ Statistical test } \\
\hline & \multicolumn{2}{|c|}{ Man-made } & \multicolumn{2}{|c|}{ Natural } & \multirow[b]{2}{*}{$\begin{array}{c}\text { ANOVA test } \\
p \text {-value }=0.01\end{array}$} & \multirow[b]{2}{*}{$\begin{array}{l}\text { Percentage } \\
\text { different (\%) }\end{array}$} \\
\hline & Mean & Std. Error & Mean & Std. Error & & \\
\hline Weight (g) & 12.913 & 0.675 & 10.251 & 0.656 & 0.006 & 20.615 \\
\hline Wing cord $(\mathrm{cm})$ & 11.625 & 0.140 & 12.260 & 0.136 & 0.002 & -5.462 \\
\hline Wing span $(\mathrm{cm})$ & 27.060 & 0.255 & 28.073 & 0.248 & 0.005 & -3.744 \\
\hline Tarsus (cm) & 1.196 & 0.108 & 1.049 & 0.105 & 0.331 & 12.291 \\
\hline Bill length $(\mathrm{cm})$ & 0.542 & 0.012 & 0.524 & 0.012 & 0.273 & 3.321 \\
\hline Tail length (cm) & 5.060 & 0.083 & 4.280 & 0.081 & 0.000 & 15.415 \\
\hline Body length (cm) & 11.215 & 0.144 & 10.729 & 0.140 & 0.017 & 4.333 \\
\hline
\end{tabular}

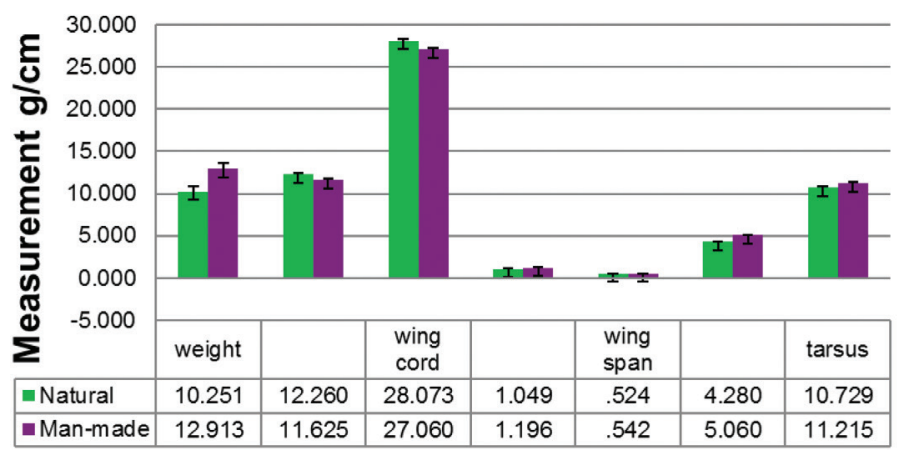

FIGURE 2. Comparison of morphology parameters (mean $\pm \mathrm{SE}$ ) $\mathrm{g} / \mathrm{cm}$ of A. fuciphagus between natural cave and man-made house 
TABLE 2. Comparison of growth parameters between A. fuciphagus and A. maximus from Gomantong Cave, Sabah

\begin{tabular}{|c|c|c|c|c|c|c|}
\hline \multirow[t]{3}{*}{ Dependent variable } & \multicolumn{4}{|c|}{ Species } & \multicolumn{2}{|c|}{ Statistical test } \\
\hline & \multicolumn{2}{|c|}{ A. maximus } & \multicolumn{2}{|c|}{ A. fuciphagus } & \multirow[b]{2}{*}{$\begin{array}{c}\text { ANOVA test } \\
p \text {-value }=0.01\end{array}$} & \multirow[b]{2}{*}{$\begin{array}{c}\text { Percentage } \\
\text { different }(\%)\end{array}$} \\
\hline & Mean & Std. Error & Mean & Std Error & & \\
\hline Weight $(\mathrm{g})$ & 12.935 & 0.345 & 8.835 & 0.251 & 0.000 & 31.697 \\
\hline Wing cord $(\mathrm{cm})$ & 12.963 & 0.205 & 11.889 & 0.149 & 0.000 & 8.285 \\
\hline Wing span $(\mathrm{cm})$ & 29.695 & 0.214 & 27.217 & 0.155 & 0.000 & 8.345 \\
\hline Tarsus $(\mathrm{cm})$ & 1.147 & 0.021 & 0.997 & 0.015 & 0.000 & 13.078 \\
\hline Bill length $(\mathrm{cm})$ & 0.558 & 0.011 & 0.506 & 0.008 & 0.000 & 9.319 \\
\hline Tail length (cm) & 4.405 & 0.165 & 4.214 & 0.120 & 0.354 & 4.336 \\
\hline Body length $(\mathrm{cm})$ & 10.937 & 0.132 & 10.619 & 0.096 & 0.057 & 2.359 \\
\hline
\end{tabular}

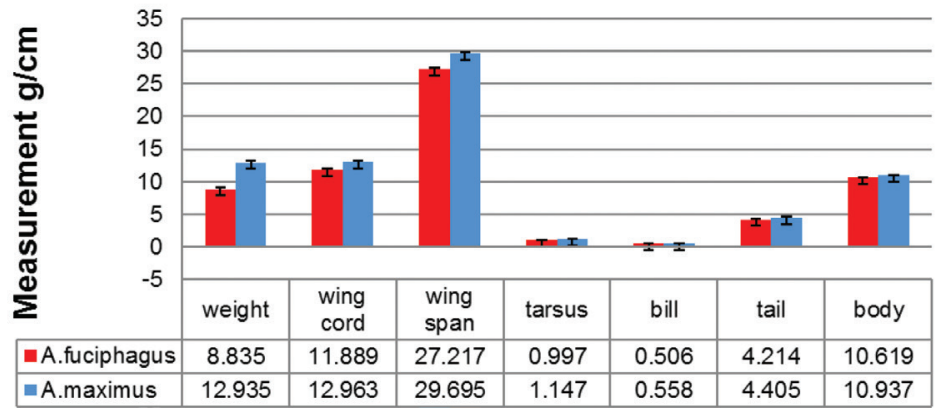

FIGURE 3. Comparison of morphology parameters (mean \pm SE) g/cm of A. fuciphagus and A. maximus from Gomantong Cave, Sabah

over genetic factors for habitat comparisons and the opposite dominance is true for species-level comparisons. In addition, diet is one of the main resource axes along which ecological separation has been achieved in many aerial insectivores (Cucco et al. 1993).

Swiftlets from different habitats showed a tendency to use various foraging areas. The swiftlets from the natural limestone cave were observed foraging around Gomantong Forest Reserve. The swiftlets from man-made bird houses have a distinct dietary variation, based on different foraging areas and their proximity to civilisation. Swiftlets from rural areas were observed foraging over surrounding gardens and oil palm plantations. In an urban area, samples were observed foraging over a patch of abandon greenbelt surrounding the area. In addition, cave swiftlets often fly close to or even under the forest canopy (Medway 1962), where larger prey may be more common than at lower altitudes. Swiftlets from man-made bird houses normally forage at higher altitudes in rural areas, where the average size of their prey is significantly smaller.

We believe the main factor contributing towards the morphological variations would be food limitation. Johnston (1993) had proved that nutritional quality will influence nestling growth of the Common house martin (Delichon urbicum) under experimental conditions. The swiftlet species in Malaysia have been shown to consume a wide variety of prey, depending on the different habitats (Tarburton 1993). A study by Lourie and Tompkins (2000) in comparing the diet composition of the Glossy swiftlet in forest, rural and urban habitats in Malaysia, showed that the dietary composition of these insectivorous birds mainly differ quantitatively and not due to the diversity of their prey. Recently, Kamarudin and Anum (2011) studied food boluses of the white-nest swiftlet from palm oil plantations in Johor and indicated that the majority of insects found were from the orders Diptera (55.7\%) and Hymenoptera (19.9\%), while the study by Lourie and Tompkins (2000) on diet components of white-nest swiftlets from Gomantong in Sabah, indicated a similar ratio betwen Diptera (39.2\%) and Hymenoptera (38.6\%). These studies suggest that swiftlets are not particularly selective in their diet composition, but react to food availability. Therefore, it is unlikely that a variation in any one prey component would significantly influence the overall growth and development of these birds. The limiting factor of white-nest swiftlet growth would be food quantity and not nutritional quality, as most of their aerial arthropod prey contains large amounts of protein and other nutrients.

The effect of weather on food availability has been studied constantly over the decades (Medway 1962; Tarburton 1993). Lack (1973) suggested that heavy rain would depress aerial insect density and reduce the foraging period of swiftlets, as he discovered that nestlings of common swifts (Apus apus) increased in weight and wing length on sunny warm days. Lack (1973) also found 
that adult swifts fed chicks with larger insects on warm days. Hespenheide (1975) further found that although there were higher densities of flying insects during wet weather, the insects seemed to swarm most during dry weather. Tarburton (1993) studied nestling growth of the white-rumped swiftlet at different seasons and reported that wings of nestlings grew significantly faster under favourable conditions. In addition, Reichel et al. (2007) suggested that good breeding periods required both abundant food supply and low rain fall.

In Malaysia, A. fuciphagus and A. maximus mainly lay and hatch most eggs from November to March (Langham 1980). This presumably relates to the period of maximal availability of insect forage to support breeding, as frequent rain will reduce the foraging time of birds and cause unhealthy nestling development. Shanmuganathan and Narayanan (2012) showed that Borneo (Sabah and Sarawak) generally experiences greater rainfall compared to Peninsular Malaysia. This explains morphological variations among swiftlets from the natural cave and man-made bird houses, as the swiftlets from the cave experience greater limitation of food, due to prolonged wet seasons.

The effects of food availability on nestling growth has been studied through a series of experiments, based on clutch and brood size manipulation and supplemental feeding. However, results of such attempts vary greatly among swiftlet species. The Pichorim and MonteiroFilho (2008) research on the relationship of brood size and nestling growth of the Biscutate swift (Streptoprocne biscutata, Aves: Apodidea) indicated that the brood size did not influence nestling growth. Similar results were also found in Apus apus, where there was no significant difference in the weight gain of nestlings from different brood sizes (Pellantová 1975). However, Langham (1980) showed that weight gain and wing growth may vary insignificantly between broods of different sizes for A. fuciphagus and A. maximus. It was suggested that brood size is basically influenced by two factors: Skill to feed the nestlings and prevention of unsuccessful reproduction caused by over-laying of eggs (Lee \& Kang 1994). Therefore, the nestling growth of swiftlets most probably relates to food limitation, in the form of insect availability.

Previous literatures indicated there were significant differences among the diets of various swiftlet species, due to geological separation and morphological variations (Collins et al. 2009; Lourie \& Tompkins 2000; Tarburton 1986). Black-nest swiftlets appeared to target larger-bodied prey than white-nest swiftlets (Harrisson 1972). Such a forging mechanism may be related to the larger body size of the black-nest swiftlet and reduction in manoeuvrability, resulting in it being less capable of chasing smaller prey. Waugh and Hails (1983) indicated that the smaller and lighter body size of Collocalia esculenta allowed it to capture fast-flying prey, compared with other swiftlet species. In addition, study on the diet of the Malaysian swiftlet species from both cave and man-made habitats, indicated that food boluses of black-nest swiftlets contained fewer prey items compared to other swiftlet species and mainly consisted of Hymenoptera (89\%), whilst the diet of white-nest swiftlets mainly consisted of Hymenoptera and Diptera (Lourie \& Tompkins 2000).

\section{CONCLUSION}

This study has shown that the white-nest swiftlet living in man-made bird houses is generally larger in body size compared to the cave swiftlet, probably due to food limitations in different geographical areas. This study further justifies that the body size of the black-nest swiftlet is greater compared to the white-nest swiftlet, in a similar geological and climactic environment.

\section{REFERENCES}

Brooke, R.K. 1970. Taxonomic and evolutionary notes on the subfamilies, tribes, genera and subgenera of the swifts (Aves: Apodidae). Durban Museum Novitates 9: 13-24.

Chantler, P. \& Driessens, G. 2000. Swifts: A Guide to the Swifts and Treeswifts of the World. United Kingdom: A \& C Black.

Collins, C.T., José, L.T. \& Brian, D.C. 2009. Food habits of the alpine swift on two continents: Intra-and interspecific comparisons. Ardeola 56: 259-269.

Cucco, M., Bryant, D.M. \& Malacarne, G. 1993. Differences in diet of common (Apus apus) and Pallid (A.pallidus) swifts. Avocetta 17: 131-138.

Dayrat, B. 2005. Towards integrative taxonomy. Biological Journal of the Linnean Society 85(3): 407-415.

Harrisson, T. 1972. The food of Collocalia swiftlets (Aves: Apodidae) at Niah Great Cave in Borneo. Journal of Bombay Natural History Society 71: 376-392.

Hespenheide, H.A. 1975. Selective predation by two swifts and a swallow in Central America. International Journal of Avian Science 117(1): 82-99.

Johnston, R.D. 1993. Effects of diet quality on the nestling growth of a wild insectivorous passerine, the house martin Delichon urbica. Functional Ecology 7:255-266.

Kamarudin, M.I. \& Anum, M. 2011. Foraging activity of Aerodramus fuciphagus swiftlet over oil palm canopy and its effect on Elaeidobius spp. pollinator population. Proceedings 32nd Annual Conference of Malaysian Society of Animal Production. Tawau, Sabah.

Lack, D.L. 1973. Swifts in a Tower. New York: Halstead Press.

Langham, N. 1980. Breeding biology of the edible-nest swiftlet Aerodramus fuciphagus. International Journal of Avian Science 122(4): 447-461.

Lee, P.L., Dale, H.C., Richard, G. \& Page, R.D. 1996. Does behavior reflect phylogeny in swiftlets (Aves: Apodidae)? A test using cytochrome $\mathrm{b}$ mitochondrial DNA sequences. Proceedings of the National Academy of Sciences USA 93(14): 7091-7096.

Lee, P.G. \& Kang, N. 1994. The reproductive strategies of ediblenest-swiftlets (Aerodramus spp.). Bulletin of the British Ornithologists' Club 114(2): 106- 113.

Lim, C.K. \& the Earl of Cranbrook. 2002. Swiftlets of Borneo: Builders of Edible Nests. Malaysian: Natural History Publications (Borneo). 
Lourie, S.A. \& Thompkin, D.M. 2000. The diets of Malaysian swiftlets. International Journal of Avian Science 142(4): 596-602.

Mayr, E. 1942. Systematics and the Origin of Species, from the Viewpoint of a Zoologist. London: Harvard University Press.

Medway, L. 1966. Field characters as a guide to the specific relations of swiftlets. Proceedings of the Linnean Society of London 177(2): 151-172.

Medway, L. 1962. The swiftlets (Collocalia) of Niah Cave, Sarawak. International Journal of Avian Science 104(1): 45-66.

Oberholser, H.C. 1906. A monograph of the genus Collocalia. Proceedings of the Academy of Natural Sciences of Philadelphia. pp. 177-212.

Pellantová, J. 1975. The course of breeding of the swift (Apus apus Linn.). Zoologické Listy 24(3): 249-262.

Pichorim, M. \& Monteiro-Filho, E.L.A. 2008. Brood size and its importance for nestling growth in the Biscutate swift (Streptoprocne biscutata, Aves: Apodidae). Brazilian Journal of Biology 68(4): 851-857.

Price, J.J., Johnson, K.P. \& Dale, H.C. 2004. The evolution of echolocation in swiftlets. Journal of Avian Biology 35(2): 135-143.

Reichel, J.D., Charles, T.C., Derek, W.S. \& Vicente, A.C. 2007. Growth and development of the Mariana swiftlet. The Wilson Journal of Ornithology 119(4): 686-692.

Salomonsen, F. 1983. Revision of the Melanesian swiftlets (Apodes: Aves) and their conspecific forms in the IndoAustralian and Polynesian region. Biologiske Skrifter Kongelige Danske Videnskabernes Selskab 23(5): 1-112.

Shanmuganathan, S. \& Narayanan, A. 2012. Modelling the climate change effects on Malaysia's oil palm yield. Proceedings of 2012 IEEE Symposium, Kuala Lumpur, Malaysia.

Sibley, C.G. 1990. Distribution and Taxonomy of Birds of the World. London: Yale University Press.

Sims, R.W. 1961. The identification of Malaysian species of swiftlets Collocalia. International Journal of Avian Science 103(2): 205-210.
Tarburton, M.K. 1993. Determinants of clutch size in the tropics: With reference to the white-rumped swiftlet. Italian Journal of Ornithology 17: 103-175.

Tarburton, M.K. 1986. The food of the white-rumped swiftlet (Aerodramus Spodiopygius) in Fiji. Notornis 332: 1-6.

Thomassen, H.A., den Tex, R.J., de Bakker, M.A. \& Povel, G.D.E. 2005. Phylogenetic relationships amongst swifts and swiftlets: A multi locus approach. Molecular Phylogenetics and Evolution 37(1): 264-277.

Thomassen, H.A., Wiersema, A.T., de Bakker, M.A., de Knijff, P., Hetebrij, E. \& Povel, G.D.E. 2003. A new phylogeny of swiftlets (Aves: Apodidae) based on cytochrome-b DNA. Molecular Phylogenetics and Evolution 29(1): 86-93.

Viruhpintu, S., Thirakhupt, K., Pradatsundarasar,A.\& Poonswad, P. 2002. Nest-site characteristics of the edible-nest swiftlet Aerodramus fuciphagus (Thunberg, 1812) at Si-Ha Islands, Phattalung Province, Thailand. Natural History 2(2): 31-35.

Waugh, D.R. \& Hails, C.J. 1983. Foraging ecology of a tropical aerial feeding bird guild. International Journal of Avian Science 125(2): 200-217.

\section{Looi Qi Hao}

Institute of Bioscience, Universiti Putra Malaysia 43400 Serdang, Selangor Darul Ehsan Malaysia

Looi Qi Hao, Aini Ideris, Md Zuki bin Abu Bakar @ Zakaria \& Abdul Rahman bin Omar*

Faculty of Veterinary Medicine, Universiti Putra Malaysia 43400 Serdang, Selangor Darul Ehsan Malaysia

*Corresponding author; email: aro@upm.edu.my

Received: 23 June 2014

Accepted: 4 November 2014 